\section{Arctic Archipelago}

British Expedi- $\left\{83 \frac{1}{2}^{\circ} \mathrm{N}\right.$. Floeberg Reach (Nares) - 73.7 F. tions, $1875-76$. $381 \frac{1}{2}^{\circ} \mathrm{N}$. Discovery Bay (Nares) $-70^{\circ} 7 \mathrm{~F}$.

The temperature at Werkhojansk is the lowest of all given here, and it must be borne in mind that the observations lasted but one year, while we have more than thirty-five years at Yakutsk, and eight and a half at Yenisseisk.

The mean temperatures are as follows :-

\begin{tabular}{|c|c|c|c|c|c|c|c|}
\hline & Year & July & Nov. & Dec. & Jan. & Feb. & March \\
\hline $\begin{array}{l}\text { Ustjansk } 2 \text { years } \\
\text { Werkhojansk I year } \\
\text { Yakutsk 10 years I } \\
\text { Yakutsk } 24 \text { years }{ }^{2} \\
\text { Floeberg Beach I yr. } \\
\text { Discovery Bay } 1 \text { yr. }\end{array}$ & $\begin{array}{r}- \\
2 \cdot 8 \\
4.3 \\
12 \cdot 2 \\
12 \cdot 4 \\
-\quad 3.5 \\
-4.2\end{array}$ & $\begin{array}{l}52^{*} \cdot \\
60 \cdot 1 \\
66 \cdot 5 \\
63 \cdot 3 \\
3^{8} \cdot 3 \\
37^{\circ} \cdot 2\end{array}$ & $\begin{array}{r}2.1 \\
-2.2 \\
-29.2 \\
-20.5 \\
-19.1 \\
-16.8 \\
-18.4\end{array}$ & $\begin{array}{l}-9 \circ 0 \\
-33^{\circ} \circ \\
-46.8 \\
-41.9 \\
-37.8 \\
-22.2 \\
-24^{\circ} 5\end{array}$ & $\begin{array}{l}-13.1 \\
-38.9 \\
-55.5 \\
-46.8 \\
-41.4 \\
-33.0 \\
-40^{\circ} 7\end{array}$ & $\begin{array}{l}-13.2 \\
-36.9 \\
-54.5 \\
-37.7 \\
-30^{\circ} 8 \\
-38.0 \\
-35^{\circ} \circ\end{array}$ & $\begin{array}{l}-6.9 \\
-175 \\
-29.0 \\
-0.0 \\
-8.7 \\
-39.8 \\
-37.4\end{array}$ \\
\hline
\end{tabular}

Though the observations were made only during one year at Werkhojansk, it is probable that it would have the coldest winter of all observed till now, as even at Yakutsk, which is the next coldest, January and February were in no single year colder than at Werkhojansk in 1869. From a comparison with the other stations of North-east Siberia it is probable that here in 1869 February was too cold and December too warm.

Now as to the reason why the winter should be colder in North-east Siberia than on the North American Archipelago farther to the north, it is to be found in the extent of the continent, the distance from any sea open in winter, and the prevailing calms. How important is the last reason is best seen by the comparison of the December and January temperatures of the last British expedition. The more northerly Floeberg Beach is warmer, because more exposed to winds. Now in Eastern Siberia calms prevail to a large extent in winter, except near the coast.

There is a phenomenon to be considered, which is noticed everywhere in winter in high latitudes: during calms with clear sky the valleys are colder than the surrounding hills and slopes, because the cold air sinks downwards and stagnates there. This is confined to the night where the mid-day sun rises high enough, but in high latitudes during some months the mid-day heat of the sun is too small and the day too short to interfere much with the equilibrium of the strata of air established during the night. Even in middle latitudes $\left(45^{\circ}-50^{\circ}\right)$, when calms and clear weather prevail very largely in December, the valleys are regularly colder than the hills. So it was felt in December, 1879, in Central Europe. What is en exception here is the rule in North-East Siberia, because calms and clear sky are the rule in winter; the valleys are much co!c'cr than the hills. On this account the exceedingly low temperature of Werkhojansk in winter is probably not common to the whole surrounding country, and especially in the mountains rising to a short distance south we may expect a much higher temperature. The more we consider the conditions of the winter temperature of North-East Siberia, the more difficult it seems to draw isotherms. We know that plains and valleys there are colder than hills and mountain-slopes, but how much, and what conditions are most favourable to that so-called interversion of temperature? I consider it as highly probable that both at Yakutsk and at Werkhojansk the local topographical conditions are very favourable to winter cold. This being the case, it is quite natural that the latter place is colder in winter than the former, being situated $5^{\circ}$ farther to the north, and yet far enough from the west to have a continental climate.

A. WOEIKOF

\section{SPHYGMOGRAPHY}

THE pulse has in all ages been held by physicians to be a valuable aid to the diagnosis of disease, but until the invention of the sphygmograph, or pulse-writer, the determination of the character of the pulse was left to the tutored tact of the doctor's finger, which varies much in delicacy of perception in different operators, and in the same practitioner at different times. At most the finger, even of the most experienced, can only detect, regarding the pulse, that it is soft or hard, quick or slow, jerky or lariguid, regular or irregular; but the finger is incapable of analysing the beats, and detecting any departure from the normal standard of each of their component elements. The sphygmograph, which is quite a modern invention, causes the pulse to write its own autograph, enables us to see at a glance the peculiar characters of the pulse, and to ascertain how and where it differs from the healthy or normal pulse.

Hitherto, however, the sphygmograph has been but little used, for those that have been introduced are large and expensive instruments, requiring a great amount of skill and trouble to fix them on the arm and bring them into action; and for these reasons they are not available for general or private practice. Hence their use has almost been confined to hospital practice; but even here

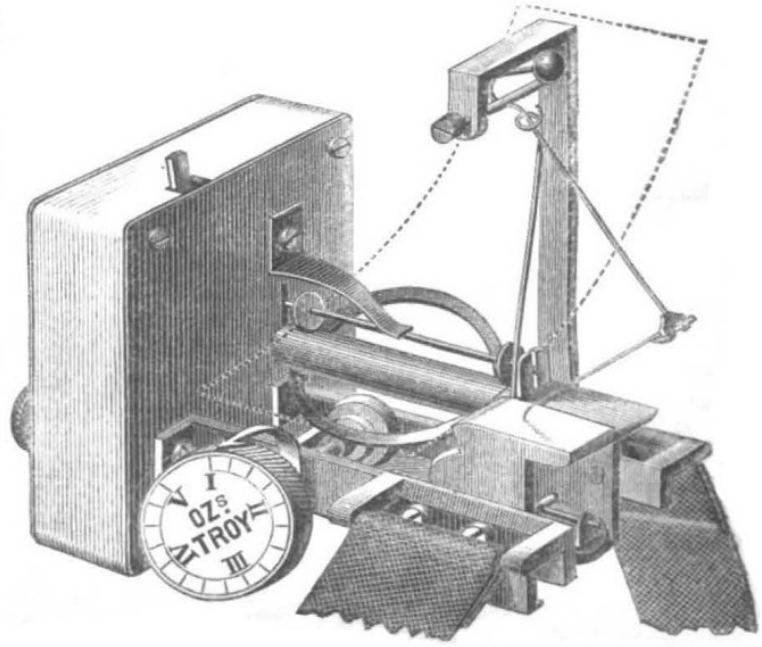

they are not always available, for Dr. B. Bramwell, who is a strong advocate for employing the sphygmograph, relates that a patient of his was so terrified by the proposal to employ the instrument that he preferred leaving the hospital to allowing it to be fixed on his arm.

The objections to the general use of the sphygmograph do not apply to the instrument recently introduced into medical practice by Dr. Dudgeon, and from its portability called "the pocket sphygmograph." 'Though this instrument is so small as to deserve the name of "pocket," it is not inferior in sensitiveness to the most elaborate and complicated of the cumbrous instruments hitherto in use, indeed in some respects it is greatly superior in accuracy to any that have yet appeared. Its size is $2 \frac{1}{2}$ by 2 inches; its weight only four ounces. It magnifies the movements of the artery exactly fifty times. The spring that presses on the artery can be regulated to press with a weight of from one to five ounces, and the pressure can be altered at will while the instrument is in situ. It requires no wrist-rest; all the other sphygmographs have to be used with wrist-rests of more or less complexity. It can be used with equal facility whether the patient is standing, sitting, or lying. With it an accurate and extremely distinct tracing of the pulse can be made almost as quickly as the pulse can be felt with the finger. Its

\footnotetext{
I According to Maak.

2 Older series of Neverof (1829-54).
} 
construction is so simple that if accidentally broken any watchmaker can repair it. The smoked paper on which the pulse is recorded runs through the instrument in ten seconds, so that the number of the beats per minute can be reckoned by multiplying the pulse-tracings on the paper by six. The patient's name, the date, the disease, the pressure of the spring, and some conventional sign to indicate his position when the tracing was made, may be written on the marked paper with any sharp-pointed instrument, such as a pin or a toothpick, and the whole permanently fixed by dipping the paper in some quickly-drying varnish, such as is used by photographers. In this way a series of pulse-tracings taken during the course of the disease may be preserved for future study and comparison.

Dr. Dudgeon's pocket sphygmograph is manufactured by Mr. John Ganter, 19, Crawford Street, W. The woodcut represents its actual size.

\section{NOTES}

WE understand that the fifth volume of the Catalogue of Birds in the British Museum will shortly be published. According to the classification followed in this work the families to be described will be the Thrushes and Warblers, and the volume will be written by Mr. Henry Seebohm, whose co-operation Dr. Günther has been fortunate in obtaining. Mr. Seebohm has devoted a close study of several years to these families of birds, and may now be considered the best living authority on the subject.

M. Flammarion, the author of several works in popular astronomy, has been made a Knight of the Légion d'Honneur. Admiral Mouchez, director of the Paris Observatory, has consented to act as his parrain, and to hand over to him the star and ribbon. This liberal determination has created some sensation in the French astronomical world. The work of transformation of the Observatory will begin very shortly, all the legal difficulties having been solved. The area of the establishment is now 30,000 square metres. The magnetical instruments will be placed in the deep trenches separating the old ground from the newly annexed buildings.

WE regret to have to announce the death of $M$. Eugène Cortambert, author of a number of geographical works, honorary president of the Geographical Society of Paris, and head of the geographical department in the National Library.

AвоUт a year ago Admiral Mouchez asked for a credit of 4000 francs per year in order to publish a monthly astronomical review. M. Jules Ferry refused the grant, but a similar review is now being published at Brussels under the name Ciel et Terre. It appears twice a month, and is devoted to meteorology and astronomy.

Although our Government has declared the interest which it takes in the forthcoming International Exhibition of Electricity at Paris, still it sees no necessity for appointing a Special Commissioner to take measures with regard to the participation of British subjects in the Exhibition which is to open in Paris on August I next in the Champs Elysées Palace. The French Government is nevertheless disposed to welcome all British subjects wishing to participate in the Exhibition. M. Berger, the Commissaire-Général, has placed himself unreservedly at the disposal of intending exhibitors to afford every information and assistance. He would be thankful if they would fill up and return to his address the printed form of demand of admission which accompanies the copy of the general regulations. English exhibitors will be placed in every respect on the same footing as French exhibitors. M. Berger will forin a special section for the group of English exhibitors, and requests that all demands be forwarded within the briefest delay possible. The Exhibition rooms and dependencies will be considered as real Custom-house stores, so that all the articles sent there shall be exempt from the duties to which they would otherwise have been liable. The French railway companies have consented to an abatement of 50 per cent. on the ordinary rates of transport, whether by fast or by slow trains, for all packages or boxes forwarded to the Exhibition Hall, and bearing the official labels. The Postmaster-General has been authorised by the British Government to exhibit in the name of the latter.

A COMMITTEE has been formed at Dijon for erecting a statue to Carnot, the celebrated French geometer and politician, who was born in Nolay, a small country town of Burgundy, in 1753. The youngest son of Carnot is now living, one of the members of Senate, and his grandson is M. Sadi Carnot, the present Minister of Public Works. The other son of Carnot died fifty years ago, after having written a small essay, "Sur la Puissance motive du feu." M. Carnot's brother has just published a new edition of this work, with a number of essays, mostly unpublished, by the same author, and a history of his life.

Ar the conclusion of the proceedings of the Quekett Microscopical Club on February 25 occasion was taken to present to Mr. J. E. Ingpen a memorial of the esteem in which he is held and the appreciation of his services as honorary secretary for the last eight years. After an able address by Dr. Matthews, setting forth the reasons which had led to this movement on the part of the members, and short speeches by Dr. Cobbold, Mr. Crisp, and Mr. Michael, Mr. T. C. White handed to Mr. Ingpen a beautifully illuminated and framed memorial, together with a valuable microscope by Zeiss and a handsome silver tea-service, which were accepted and acknowledged amidst hearty demonstrations of good feeling on the part of the meeting. The attendance of members was unusually large, and in the course of the evening telegrams were received from Dr. M. C. Cooke and Mr. Henry Lee, expressing their regret at unavoidable absence.

AT the ordinary meeting of the Meteorological Society, to be held at 25 Great George Street, Westminiter, on Wednesday, the I6th inst., at 7 p.m., there will be an exhibition of instruments, consisting of various kinds of hygrometers and of such new instruments as have been brought out since January I, 1880 . During the evening the President will give a historical sketch of the different classes of hygrometers, and will also describe such forms as are exhibited.

THE town of Casamicciola, in the Island of Ischia, has been almost entirely destroyed by an earthquake. More than 200 houses have been thrown down, and many others are so much damaged as to be uninhabitable. The number of persons thus far ascertained to have been killed is 104, and very many more have been injured. The total number of victims is estimated at 300. This dreadful catastrophe was the result of two shocksthe first at half-past one in the afternoon of the $4^{\text {th }}$ inst., lasting seven seconds; the second after an interval of an hour and a half. The whole upper part of the town has been destroyed. The handsome Albergo della Grande Sentinella is a mass of ruins. Clefts and fissures opened in the streets 50 centimetres in width. It was at first supposed that this disaster was connected with the partial eruption of Vesuvius on the 3 rd inst., but Prof. Palmieri has stated that the seismographic instruments having given no indications, he is inclined to think the catastrophe is due to some local phenomenon, possibly to a sudden sinking of the ground through subterranean corrosion caused by the continual working of the mineral waters. Shortly before the first shock of earthquake the mineral springs were observed to be in a state of ebullition. Another shock was felt at midnight.

SHocks of earthquake occurred at St. Ivan-Zelina (Hungary) on February 26 at $3 \mathrm{~h} .54 \mathrm{~m}$, in the night of February $26-27$ at 